удК 343.98.06

O. А. Самойленко

\title{
ТИПОВІ СЛІДЧІ СИТУАЦІЇ НАСТУПНОГО ЕТАПУ РОЗСЛІДУВАННЯ ЗЛОЧИНІВ, СКОСНИХ У КІБЕРПРОСТОРІ
}

Постановка проблеми. Можливості кіберпростору призводять до скоєння злочинів у різних сферах суспільних відносин: від національної безпеки до відносин власності чи у сфері конституційних прав та свобод людини й громадянина. Динаміку зростання злочинності у кіберпросторі віддзеркалюють обліковувані Департаментом організаційно-аналітичного забезпечення Національної поліції України відомості про кримінальні правопорушення, вчинені з використанням високих інформаційних технологій (у тому числі виявлені та супроводжувані працівниками кіберполіції). Так, у 2014 році у провадженні підрозділів Національної поліції перебувало 4883 таких злочинів; у 2015 - 6026; у 2016 - 6219; у 2017 - 10872; у 2018 - 11131. Об'єднує такі злочини використана для досягнення злочинного результату обстановка кіберпростору, що зумовлює необхідність застосування єдиних методів, засобів і прийомів вирішення практичних завдань на початковому та наступному етапі розслідування вказаної злочинної діяльності.

Аналіз останніх досліджень і публікацій. Вітчизняні криміналісти П.Д. Біленчук, А.С. Білоусов, В.О. Голубєв, М.В. Гуцалюк, М.Ю. Літвінов, О. І. Мотлях, І.М. Осика, Л.П. Паламарчук, А.В. Реуцький, С.М. Рогозін, Б.В. Романюк, М.В. Салтевський, С.В. Самойлов, К.В. Тітунініна, Д.М. Цехан, В.С. Цимбалюк, В.П. Шеломенцев, С.С. Чернявський у своїх роботах з проблематики розслідування злочинів, скоєних у кіберпросторі, приділяють увагу розслідуванню окремих видів таких злочинів або в цілому способам протидії кіберзлочинності у розумінні однойменної Конвенції Ради Європи. Через особливу значущість у криміналістичному аспекті слідчих ситуацій початкового етапу розслідування злочинів ситуації наступного етапу розслідування злочинів, скоєних у кіберпросторі, майже не потрапляють у поле зору науковців.

Метою статті є визначення типових слідчих ситуацій наступного етапу розслідування на підставі узагальнення матеріалів кримінальних проваджень про злочини, вчинені у кіберпросторі.

Виклад основного матеріалу дослідження. Типова слідча ситуація - це наукова абстракція, утворена на підставі апріорних знань, $є$ результатом узагальнення й аналізу емпіричного матеріалу, у ній відображено найбільш загальні риси, що характеризують перебіг і стан розслідування на певному етапі (вихідному, початковому, наступному) [1, с. 106]. Високий ступінь наукової абстракції зумовлює іï вагоме теоретичне та методичне значення для розроблення низки питань криміналістики. Якщо конкретна ситуація є відображенням стану досудового розслідування конкретного кримінального провадження, то типова $є$ результатом наукового узагальнення слідчої практики [2, с. 118-119]. Отже, зміст типових слідчих ситуацій слід інтерпретувати через особливості організації слідчої діяльності в сучасних правових умовах на відповідному криміналістичному етапі розслідування. 
Слідчі ситуації наступного етапу розслідування, зумовлені ними комплекси тактичних завдань і засоби виконання останніх традиційно корегувалися зі ставленням підозрюваного до розслідування злочину; наявність протидії з боку підозрюваного визначала складність ситуації наступного етапу розслідування.

Втім, нині можна висновувати про принципово новий характер діяльності слідчого на наступному етапі розслідування, він пов'язаний із сучасною інформаційною моделлю злочину, яка має ознаки багатоепізодної злочинної діяльності, зумовлена необхідністю виявлення злочинного наміру встановленої або невстановленої особи співучасника злочину, специфікою розподілу ролей учасників злочинної групи під час скоєння злочину організованою групою. Аналіз матеріалів практики розслідування злочинів, скоєних у кіберпросторі, та результати анкетування практичних працівників засвідчують, що ступінь складності, трудомісткості досудового розслідування злочинів пов'язаний нині передусім із кількістю епізодів злочинної діяльності й осіб, які брали в ній участь або продовжують її вчиняти.

У цьому сенсі законодавець щодо досудового розслідування чітко окреслює межу розшукової та слідчої діяльності - це неможливість отримати відомості про злочин та особу, яка його скоїла, в інший спосіб, ніж проведення негласних слідчих (розшукових) дій. Двовекторність тактичних завдань розслідування дає підстави виокремлювати слідчу та слідчо-розшукову моделі типових ситуацій розслідування. Адже, як справедливо відзначає В.А. Журавель, одним із суттєвих критеріїв типізації слідчих ситуацій є саме ступінь їх впливу на процес формування стратегічних і тактичних завдань розслідування й визначення оптимальної послідовності проведення слідчих дій або тактичних операцій, що спрямовані на виконання цих завдань [3].

Слідчо-розшукова модель ситуації (або слідчо-розшукова ситуація) передбачає наявність фактичних даних про злочинні наміри встановленої/невстановленої особи або групи осіб учинити кримінальне правопорушення, вона визначає такі напрями діяльності слідчого, як виявлення, викриття та документування злочинної діяльності особи або групи осіб. Для цього слідчий має обрати відповідний комплекс слідчих (розшукових) дій, обов'язковим елементом якого є негласні слідчі (розшукові) дії. Типові слідчо-розшукові ситуації початкового та наступного етапів розслідування мають динамічний характер, невиконання хоча б одного із тактичних завдань у слідчо-розшуковій ситуації початкового етапу розслідування призводить до виникнення аналогічної моделі ситуації на наступному етапі. У слідчо-розшукових ситуаціях розслідування злочинів, скоєних у кіберпросторі, можна визначити такий перелік типових тактичних завдань (характерним $є$ для початкового та наступного етапів розслідування), зокрема:

- документування мотиву злочинної діяльності кожного учасника злочинної групи;

- виявлення осіб у складі групи, які не були обізнані щодо вчинення злочину (виконували дії, які не заборонені законодавством України, наприклад: адміністративні або технічні функції, розроблення сайту, надання послуг з його розміщення тощо); 
- виявлення зв'язків між учасниками групи, причинно-наслідкових зв'язків, що засвідчують наявність корупційного складника злочинної діяльності, міжрегіональних, транснаціональних злочинних зв'язків;

- визначення функцій кожного учасника групи, конкретизація ролі кожного учасника групи;

- встановлення методів конспірації злочинної діяльності групи, методів підтримки бездоганного авторитету її керівників, що могли формувати у співучасників упевненість стосовно можливості ухилитися від відповідальності за скоєння групових злочинів у разі їх виявлення правоохоронними органами;

- недопущення настання запланованого результату особливо тяжкого злочину.

Слідча модель ситуації (далі - слідча ситуація) характеризується наявністю фактичних даних про вчинення кримінального правопорушення та/або особу злочинця. Тому типізація моделей слідчих ситуації дасть змогу слідчому забезпечити повноту розслідування - доказування події злочину, винуватості конкретної особи у вчиненні кримінального правопорушення (форми вини, мотивів і мети вчинення кримінального правопорушення) й інших обставин, коло яких має релевантне значення, тобто тих, що відповідають пошуковому завданню слідчого з метою доказування ознак складу конкретного кримінального правопорушення.

Із 2014 року розслідування може здійснюватися в досить специфічній формі кримінального провадження, яка має назву «спеціальне досудове розслідування» [4]. Вона регламентована главою 24-1 КПК України та пов'язана із фізичною відсутністю підозрюваного під час фактичного продовження розслідування за участю сторони захисту в особі захисника підозрюваного. Тому фактично в тактичному плані позиція підозрюваного через його фізичну відсутність на наступному етапі розслідування залишиться спірною, що робить некоректними наявні рекомендації зі здійснення наступного етапу розслідування окремих видів злочинів. За таких обставин ураховувати позиції навіть усіх підозрюваних у кримінальному провадженні для типізації слідчих ситуацій наступного етапу розслідування не досить.

Знаний вчений Г.А. Матусовський у цьому контексті використовує такий критерій, як «стан розслідування», трактуючи його як упорядковану сукупність установлених у процесі розслідування обставин, оцінювану слідчим як положення, що сприяє провадженню в справі або створює перешкоди, тому потребує прийняття відповідних слідчих рішень для використання (розвитку) сприятливої ситуації або вирішення (розрядження) ситуації несприятливої (складної, конфліктної) [5, с. 143].

Аналіз матеріалів судово-слідчої практики дає підстави визнати, що стан розслідування зумовлений ступенем виконання тактичних завдань початкового етапу розслідування, характеру на момент реєстрації в Єдиному реєстрі досудових розслідувань (ЄРДР) інформації щодо висунення принаймні одній особі законної та обгрунтованої підозри у вчиненні кримінального правопорушення. Стан розслідування має бути оцінений з метою визначення моделі ситуації, у якій слідчому доведеться розпочинати наступний етап розслідування, а також конкретизації зумовлених динамікою початкового етапу розслідування обставин, коло яких має релевантне значення щодо майбутньої слідчої ситуації. 
Відповідно до загального стану розслідування на момент реєстрації в ЄРДР інформації щодо висунення першої законної та обгрунтованої підозри, а також зайнятої підозрюваним у кримінальному провадженні позиції на наступному етапі розслідування злочинів, скоєних у кіберпросторі, може бути виокремлено дві типові слідчі ситуації.

1. Сприятлива слідча ситуація розслідування, що характеризується повнотою виконання тактичних завдань розслідування, конкретизацією зайнятих кожним з підозрюваних у кримінальному провадженні позицій. Однак стосовно розслідування злочинів, скоєних у кіберпросторі, однаково поширеними є два її різновиди:

1) неускладнена сприятлива ситуація, що складається за умови збігу позицій підозрюваних осіб та співпраці їх зі слідством;

2) ускладнена сприятлива ситуація, що наявна за умови розбіжності позицій декількох підозрюваних. 3 тактичних позицій ця ситуація вимагатиме виконання таких тактичних завдань розслідування:

- подолання протидії розслідуванню;

- усунення суперечностей між джерелами доказового значення;

- забезпечення збереження вже отриманих джерел доказів.

Засобами виконання цих завдань розслідування є:

- повідомлення підозрюваного про проведення негласних слідчих (розшукових) дій (використання фактора «раптовості» на наступному етапі розслідування);

- комплекс одночасних допитів декількох осіб (з метою подолання суперечностей у показаннях);

- комплекс слідчих експериментів (з кожним виконавцем злочину);

- допити свідків (понятих і спеціалістів);

- подальші організаційні заходи, спрямовані на збирання матеріалів, що характеризують особу підозрюваного;

- додаткові допити підозрюваних.

2. Несприятлива слідча ситуація розслідування. Їй притаманні виконання пізнавальних завдань розслідування та невизначеність зайнятої підозрюваним(ми) у кримінальному провадженні позиції. Для типізації завдань наступного етапу розслідування можна розглянути кримінальне провадження щодо групи осіб, які 2017 року за попередньою змовою шляхом несанкціонованого втручання в роботу мереж ТОВ «ТРК...» незаконно ретранслювали телевізійні канали, право на яке має ТОВ «ТРК...», унаслідок чого група осіб здійснила порушення встановленого порядку маршрутизації інформації електрозв'язку й авторських і суміжних прав шляхом незаконного відтворення програм мовлення, чим завдали ТОВ «ТРК...» майнових збитків у розмірі 256000 грн. На початковому етапі розслідування цього кримінального провадження склалася слідчо-розшукова ситуація (у зв'язку з деюре повідомленням особи про злочинну діяльність невстановлених осіб, що зачіпає інтереси користувачів кіберпростору в соціальній сфері). На момент оголошення підозри гр. А. у скоєнні цього злочину в матеріалах кримінального провадження було зазначено про проведення таких заходів:

1) спостереження за місцем, де встановлено обладнання для кардшарингу (після отримання відповіді з Департаменту кіберполіції Національної поліції України); 
2) контроль за скоєнням злочину, а саме спеціальний слідчий експеримент з метою фіксації відомостей щодо незаконної ретрансляції телеканалів «1» та «2»;

3) у порядку ст. 93 КПК України витребувано інформацію у ТОВ «ТРК...» про спосіб трансляції зазначених телеканалів, осіб, які отримали право на їх перегляд і ретрансляцію;

4) встановлено рух грошових коштів, які надходять на електронні гаманці веб-ресурсу (отримання інформації від ТОВ «ВЕБ МАНІ ЮА»);

5) отримано інформацію від інтернет-провайдера, який надає телекомунікаційні послуги за місцем організації ретрансляції;

6) обшук за адресами місць мешкання осіб, які причетні до вчинення цього кримінального правопорушення, і приміщень, де знаходиться обладнання, призначене для поширення незаконного контенту;

7) призначено експертизу комп'ютерної техніки та програмних продуктів й експертизу телекомунікаційних систем і засобів з метою встановлення способу скоєння злочину.

Оскільки злочинна діяльність попередньо (у підозрі) кваліфікована за ч. 2 ст. 361 , але вбачається ч. 2 ст. 176 КК України, то внаслідок проведених заходів на наступному етапі розслідування постають тактичні завдання щодо встановлення таких обставин злочину:

- кількості епізодів злочинної діяльності;

- суми завданого ТОВ «ТРК...» збитку;

- власника (правовласника) авторських і суміжних прав;

- інших осіб, які залучені в механізм скоєння злочину (правопорушення може також учинити особа, яка раніше працювала з ТОВ «ТРК...» та займалася встановленням супутникового телебачення, здійснювала поширення смарт-карток для перегляду телеканалів; цього не змогли встановити на початковому етапі розслідування у зв'язку із заходами конспірації безпосереднього виконавця злочину).

Для виконання вказаних завдань розслідування було спрямовано такий комплекс заходів:

1) тимчасовий доступ до речей і документів у ПАТ КБ «Приватбанк» щодо всіх осіб, які причетні до вчинення цього кримінального правопорушення, встановлення IP-адрес, з яких відбувався переказ грошових коштів (після отримання інформації від Департаменту кіберполіції Національної поліції України та проведення частини вищевказаних негласних слідчих (розшукових) дій);

2) тимчасовий доступ до речей і документів провайдера телекомунікацій TOB «A», які підтверджують відомості про надання доступу підозрюваному до Інтернету з наданням виділеної статичної IP-адреси;

3) тимчасовий доступ до речей і документів ТОВ «ТРК...», що засвідчують його право на трансляцію телеканалів «1» та «2», інші правовідносини, що пов’язані із цією функцією, а також містять інформацію про несанкціоноване втручання в роботу мережі ТОВ «ТРК...» під час трансляції телеканалів, що призвело до витоку та порушення встановленого порядку маршрутизації інформації;

4) слідчий огляд вилученого під час обшуків з метою визначення повторності щодо незаконного поширення телевізійних програм і передач телеканалів «1» та «2», без належного на те дозволу власника (ТОВ «ТРК...»); 
5) призначення експертизи об'єктів інтелектуальної власності з метою конкретизації матеріальної шкоди правовласнику ТОВ «ТРК...»;

6) доручення підрозділам Департаменту кіберполіції Національної поліції України в порядку ст. 40 КПК України щодо отримання та аналізу інформації від провайдерів, операторів зв'язку й телекомунікацій щодо конкретних абонентів і точок доступу (у межах виконання вимог ст. 93 КПК України), які були споживачами контенту або адміністраторами сайту;

7) подальші, аналогічні проведеним, дії за умови виявлення інших осіб, що адміністрували сайт, який використовували для протиправної ретрансляції телеканалів без належного на те дозволу власника ТОВ «ТРК...».

Проаналізований приклад засвідчує, що в контексті виконання завдань слідчої ситуації наступного етапу розслідування злочинів, скоєних у кіберпросторі, важливими факторами є:

1) проведення опитування підозрюваних до оголошення їм підозри (слідчий має відповісти на запитання: чи не призведе попереднє опитування підозрюваної особи до активної протидії розслідуванню останньою);

2) обрана слідчим послідовність оголошення підозри співучасникам злочину (зокрема, можливе одночасне повідомлення про підозру всім співучасникам або почергове повідомлення співучасників - коли слідчий, залежно від особистісних характеристик організатора, виконавців, пособників, приймає рішення про те, кому з учасників злочинної групи першому потрібно оголосити підозру, а кому останньому).

Також потрібно врахувати, що на наступному етапі розслідування повідомленням про підозру фіксують підтвердження або зміну попередньої кваліфікації події злочину. Зменшення або збільшення тяжкості останньої за певної сукупності інформації про подальший епізод злочинної діяльності визначає перспективу здійснення досудового розслідування за іншими епізодами злочинної діяльності в кримінальному провадженні (через наявність або відсутність можливості проведення негласних слідчих (розшукових) дій. За таких обставин слідча модель ситуації наступного етапу розслідування може з черговою перекваліфікацією кримінального правопорушення перетворитися на слідчо-розшукову модель ситуації розслідування.

Висновки. Типові слідчі ситуації наступного етапу розслідування злочинів, скоєних у кіберпросторі, можна розглядати у ракурсі двох моделей ситуацій: слідчо-розшуковій та слідчій. Слідчо-розшукова ситуація (модель) на наступному етапі розслідування визначає такі напрями діяльності слідчого, як виявлення, викриття та документування злочинної діяльності особи або групи осіб. Для цього обирається відповідний комплекс слідчих (розшукових) дій, обов'язковим елементом якого є негласні слідчі (розшукові) дії.

Базовими критеріями для типізації слідчих ситуацій наступного етапу розслідування злочинів, скоєних у кіберпросторі, виступають: 1) стан розслідування, що зумовлюється ступенем виконання тактичних завдань початкового етапу розслідування; 2) характер інформації щодо висунення принаймні одній особі законної та обгрунтованої підозри у вчиненні кримінального правопорушення (на момент реєстрації цієї інформації в ЄРДР). Стан розслідування має бути оцінений 
з метою визначення моделі ситуації, у якій слідчому доведеться розпочинати наступний етап розслідування.

Якщо на початковому етапі розслідування були виконані всі поставлені в умові слідчо-розшукової ситуації тактичні завдання, то на наступному етапі розслідування злочинів, скоєних у кіберпросторі, буде присутня одна з таких типових слідчих ситуацій: 1) неускладнена сприятлива слідча ситуація, що складається за умови збігу позицій підозрюваних осіб та співпраці їх зі слідством; 2) ускладнена сприятлива слідча ситуація, що наявна за умови розбіжності позицій декількох підозрюваних; 3) несприятлива слідча ситуація розслідування, якій притаманні виконання пізнавальних завдань розслідування та невизначеність зайнятої підозрюваним(ми) у кримінальному провадженні позиції.

\section{Jimepamypa}

1. Белкин Р.С. Криминалистическая энциклопедия. Москва : Мегатрон XXI, 2000. 334 c.

2. Самойленко О.А. Особливості розслідування викрадень майна, вчинених із використанням комп’ютерних технологій : монографія. Київ, 2009. 328 с.

3. Журавель В.А. Криміналістичні методики: сучасні наукові концепції : монографія. Харків : Апостиль, 2012. $304 \mathrm{c}$.

4. Про внесення змін до Кримінального та Кримінального процесуального кодексів України щодо невідворотності покарання за окремі злочини проти основ національної безпеки, громадської безпеки та корупційні злочини : Закон України від 7 жовт. 2014 р. № 1689-VII. URL: https://zakon.rada.gov. ua/go/1689-18.

5. Матусовский Г.А. Экономические преступления: Криминалистический анализ. Харьков : Консум, 1999. 480 c.

\section{Анотація}

Самойленко О. А. Типові слідчі ситуації наступного етапу розслідування злочинів, скоєних у кіберпросторі. - Стаття.

Стаття присвячена визначенню типових слідчих ситуацій наступного етапу розслідування злочинів, скоєних у кіберпросторі. Автор на підставі узагальнення матеріалів кримінальних проваджень про такі злочини констатує про наявність слідчої та слідчо-розшукової моделі таких ситуацій розслідування, встановлює критерії, що покладаються в основу типізації таких ситуацій.

Ключові слова: злочин, кіберпростір, розслідування, слідча (розшукова) дія, слідча ситуація, тактичне завдання.

\section{Аннотация}

Самойленко $E$. $A$. Типичные следственные ситуации последующего этапа расследования преступлений, совершенных в киберпространстве. - Статья.

Статья посвящена определению типичных следственных ситуаций последующего этапа расследования преступлений, совершенных в киберпространстве. Автор на основании обобщения материалов уголовных производств о таких преступлениях приходит к выводу о наличии следственной и следственно-розыскной модели таких ситуаций расследования, устанавливает критерии типизации таких ситуаций.

Ключевые слова: преступление, киберпространство, расследование, следственное (розыскное) действие, следственная ситуация, тактическая задача.

\section{Summary}

Samoilenko 0 . A. Typical investigative situations of the subsequent stage of investigation of crimes committed in cyberspace. - Article.

The article is devoted to the definition of typical investigative situations of the subsequent stage of investigation of crimes committed in cyberspace. The author, on the basis of summarizing the materials of criminal proceedings on such crimes, concludes that there is an investigative and investigative-search model of such situations of investigation, establishes the criteria for the typification of such situations.

Key words: crime, cyberspace, investigation, investigative (investigative) action, investigative situation, tactical task. 